\title{
PENGARUH PENGGUNAAN VARIASI BAHAN BAKAR PERTAMAX, PERTALITE DAN PREMIUM TERHADAP PERFORMA MESIN MOTOR INJECTION 115 CC TAHUN 2013
}

\author{
The Effect of Using Fuel Variaton Pertamax, Pertalite and Premiun on Performance of Motorcycle \\ Injection 115 CC year of 2013
}

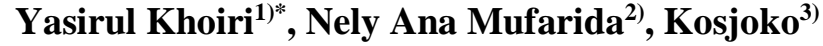 \\ ${ }^{1,2,3)}$ Program Studi S1 Teknik Mesin, Fakultas Teknik, Universitas Muhammadiyah Jember \\ *Email : yasirulkhoiri78@gmail.com
}

\begin{abstract}
ABSTRAK
Saat ini semakin banyaknya jenis kendaraan umum seperti sepeda motor membuat pengendara dapat memilih alternatif jenis bahan bakar pertamina untuk motor bensin antara lain premium, pertalite dan pertamax. Performa mesin motor dipengaruhi oleh beberapa faktor, diantaranya adalah jenis bahan bakar yang digunakan. Penelitian ini bertujuan untuk mengetahui perbedaan performa motor terhadap penggunaan variasi bahan bakar bakar premium, pertalite dan pertamax dengan melakukan pengujian daya dan torsi. Pengujian masing-masing jenis bahan bakar diuji pada mesin motor injeksi $115 \mathrm{cc}$ tahun 2013 dengan menggunakan dynotest, yang terhubung dengan komputer. pada komputer akan mencatat grafik hasil perubahan daya dan torsi dari masing-masing jenis pengujian bahan bakar. Hasil penelitian menunjukkan torsi maksimum pada pertamax sebesar 9,86 N.m pada putaran mesin $3500 \mathrm{rpm}$ dan torsi maksimum pada pertalite yaitu 9,91 N.m pada putaran mesin 3500 rpm. Sedangkan torsi tertinggi yang dihasilkan pada premium sebesar 9,67 N.m pada putaran mesin 3000 rpm. Sedangkan daya maksimum yang dihasilkan oleh premium, pertalite dan pertamax diuputaran mesin yang sama yaitu $7000 \mathrm{rpm}$ untuk premium daya tertinggi sebesar $9,3 \mathrm{hp}$ dan pertalite daya maksimum yang dihasilkan yaitu sebesar $9,3 \mathrm{hp}$. Sedangkan daya tertinggi yang dihasilkan pertamax sebesar 9,4 hp.
\end{abstract}

Kata kunci : Daya dan Torsi, premium, pertalite, pertamax

\begin{abstract}
Currently, more public vehicles such as motorbikes are use several choices of Pertamina fuel types for gasoline including premium, pertalite and pertamax. Motor engine performance is influenced by several factors, including the type of fuel used. This study aims to determine the difference of motor performance with the use of variations in premium fuel, pertalite and pertamax by testing power and torque. Testing of each type of fuel was tested on a 115 cc injection motorbike engine in 2013 using dynotest, which was connected to a computer. on the computer will record a graph of the changes in the power and torque of each type of fuel test. The results showed that the maximum torque at pertamax was 9.86 N.m at engine speed $3500 \mathrm{rpm}$ and maximum torque at pertalite which was 9.91 N.m at engine speed $3500 \mathrm{rpm}$. While the highest torque produced at the premium is $9.67 \mathrm{~N} . \mathrm{m}$ at $3000 \mathrm{rpm}$ engine speed. While the maximum power produced by premium, pertalite and pertamax is supplied by the same engine which is $7000 \mathrm{rpm}$ for the highest premium power of $9.3 \mathrm{hp}$ and the maximum power pertalite produced is 9.3 $\mathrm{hp}$. While the highest power produced by pertamax is $9.4 \mathrm{hp}$.
\end{abstract}

Keywords: Power and Torque, premium, pertalite, pertamax 


\section{PENDAHULUAN}

Motor bakar adalah mesin atau pesawat tenaga yang merupakan mesin kalor dengan menggunakan energi panas untuk melakukan kerja mekanik dengan merubah energi kimia dari bahan bakar menjadi energi panas (thermal) sehingga menghasilkan energi mekanik. Cara memperoleh energi thermal tersebut dari hasil proses pembakaran bahan bakar didalam mesin itu sendiri. Bahan bakar memegang peranan penting dalam motor bakar, nilai kalor yang terkandung didalamnya adalah nilai yang menyatakan jumlah energi panas maksimum yang dibebaskan oleh suatu bahan bakar melalui reaksi pembakaran sempurna persatuan massa atau volume bahan bakar tersebut.

Motor bakar merupakan suatu mesin konversi energi yang merubah energi kalor menjadi energi mekanik. Dengan adanya energi kalor sebagai suatu penghasil tenaga maka sudah semestinya mesin tersebut memerlukan bahan bakar dan sistem pembakaran yang digunakan sebagai sumber kalor. Motor bakar yang menggunakan bahan bakar bensin disebut dengan motor bensin dan motor bakar yang menggunakan bahan bakar solar disebut motor diesel.

Saat ini banyak sekali permasalahan yang disebabkan oleh cadangan bahan bakar minyak yang jumlahnya terbatas dengan harga yang melambung tinggi. Oleh karena itu PT. Pertamina (persero) pada pertengahan Tahun 2015 mengeluarkan bbm baru yang bernama pertalite. Pertalite merupakan jenis BBM baru yang telah diluncurkan Pertamina untuk memenuhi Surat Keputusan Dirjen Migas Kementerian Energi dan Sumber Daya Mineral Nomor 313 Tahun 2013 yang isinya menetapkan standar mutu (Spesifikasi) bahan bakar minyak jenis bensin 90 yang dipasarkan di dalam negeri. Keunggulah pertalite versi pertamina antara lain kandungan bahannya yang dinilai lebih bersih dibandingkan premium karena memiliki Research Octan Number (RON) di atas 88 yang terkandung dalam premium, Kemudian harga jual Pertalite yang lebih murah ketimbang Pertamax dengan kadar RON 92, sehingga diharapkan masyarakat akan mendapatkan BBM kualitas baik dengan harga yang lebih murah.

Respons masyarakat berbeda-beda terhadap bahan bakar baru yang diyakini lebih ramah lingkungan ini. Sebagian menolak, karena pada prakteknya pertalite tidak lebih baik dibandingkan dengan premium untuk performa mesin kendaraan mereka, sebagian lagi mendukung karena menyadari kualitas BBM di Indonesia sudah jauh tertinggal dibanding negara lain, tetangga sekalipun. Namun sebagian besar masyarakat tidak bisa berpendapat mengenai jenis bahan bakar pertalite ini, masyarakat belum mengetahui lebih jauh tentang pertalite ini karena pemerintah hanya menyampaikan beberapa keunggulannya saja, namun hasil riset dari bahan bakar pertalite ini tidak disampaikan menyeluruh kepada masyarakat.

Dikutip dalam detik forum, A. S. Tedjosiswojo selaku Senior General Manager Technical Service Division PT. Astra Honda Motor (AHM) mengungkapkan bahwa Untuk mesin sepeda motor dengan kebutuhan spesifikasi bahan bakar jenis Pertamax apabila menggunakan jenis Premium maka akan berpengaruh pada menurunnya performa dan umur pakai mesin. Sementara mesin sepeda motor dengan kebutuhan spesifikasi bahan bakar jenis Premium apabila menggunakan jenis Pertamax maka cenderung tidak berpengaruh signifikan pada performa. Pemakaian bahan bakar yang tidak sesuai spesifikasi yang dibutuhkan oleh mesin sehingga menurunnya performa mesin akan berpengaruh terhadap emisi gas buang dihasilkan. Hal ini tentu akan berpengaruh terhadap lingkungan.

Berdasarkan latar belakang yang sudah diuraikan di atas, penulis tertarik untuk melakukan penelitian tentang penggunaan variasi bahan bakar pertamax, pertalite dan premium terhadap performa mesin motor injection 115 cc tahun 2013 dalam kasus ini sebagai objek penelitian.

\section{TINJAUAN PUSTAKA}

Perfoma suatu mesin pada umumnya dapat dilihat dari tingkat torsi, daya, konsumsi bahan bakar. Pada umumnya untuk mengetahui performa suatu mesin dapat diketahui dari spesifikasi mesin dari produsen pembuat mesin tersebut. Data dan spesifikasi dari produsen tersebut dapat dijadikan suatu acuan awal besarnya performa suatu mesin atau dapat disebut juga karakter mesin bensin tersebut.

Secara umum daya berbanding lurus dengan luas piston sedang torsi berbanding lurus dengan volume langkah. Parameter tersebut relatif penting digunakan pada mesin yang berkemampuan kerja dengan variasi kecepatan operasi dan tingkat pembebanan. Daya maksimum didefinisikan sebagai kemampuan maksimum yang bisa dihasilkan oleh suatu mesin. Adapun torsi poros pada kecepatan tertentu mengindikasikan kemampuan untuk memperoleh 
aliran udara dan juga bahan bakar yang tinggi ke dalam mesin pada kecepatan tersebut. Sementara suatu mesin dioperasikan pada waktu yang cukup lama, maka konsumsi bahan bakar serta efisiensi mesinnya menjadi hal yang sangat penting.

1. Torsi dan Daya

Torsi adalah ukuran kemampuan mesin untuk melakukan kerja, jadi torsi adalah suatu energi. Besaran torsi adalah besaran turunan yang biasa digunakan untuk menghitung energi yang dihasilkan dari benda yang berputar pada porosnya.

Torsi dapat diperoleh dari hasil kali antara gaya dengan jarak :

$\mathrm{T}=\mathrm{F} \times \mathrm{b}$

Dimana : $\mathrm{T}=$ Torsi $(\mathrm{Nm}) \mathrm{F}=$ Gaya penyimbang $(\mathrm{N})$

$\mathrm{b}=$ Jarak lengan torsi $(\mathrm{m})$

Daya merupakan salah satu parameter dalam menentukan peforma motor. Perbandingan perhitunagan daya terhadap berbagai macam motor tergantung pada putaran mesin dan momen putar itu sendiri, semaki cepat putaran mesin, rpm yang dihasilkan semakin besar sehingga daya yang dihasilkan juga semakin besar, begitu juga momen putar motornya, semakin banyak jumlah gigi pada roda giginya semakin besar torsi yang terjadi. Dengan demikian jumlah putaran (rpm) dan besarnya momen putar atau torsi mempengaruhi daya motor yang dihasilkan oleh sebuah motor.

Pada motor bakar daya yang berguna adalah daya poros, dikarenakan poros tersebut menggerakkan beban. Dengan demikian besar daya poros itu adalah :

$$
P=\frac{2 \pi \cdot n \cdot T}{60000} \text {. }
$$

Dimana : $\mathrm{P}=$ Daya $(\mathrm{Hp}) \quad \mathrm{T}=$ Torsi $(\mathrm{N} . \mathrm{m})$

$\mathrm{n}=$ Putaran mesin (rpm)

\section{METODE PENELITIAN}

Metode penelitian pada pengaruh penggunaan variasi bahan bakar pertamax, pertalite dan premium terhadap performa mesin motor injection $115 \mathrm{cc}$ tahun 2013 diilustrasikan pada diagram alir gambar 3.1.

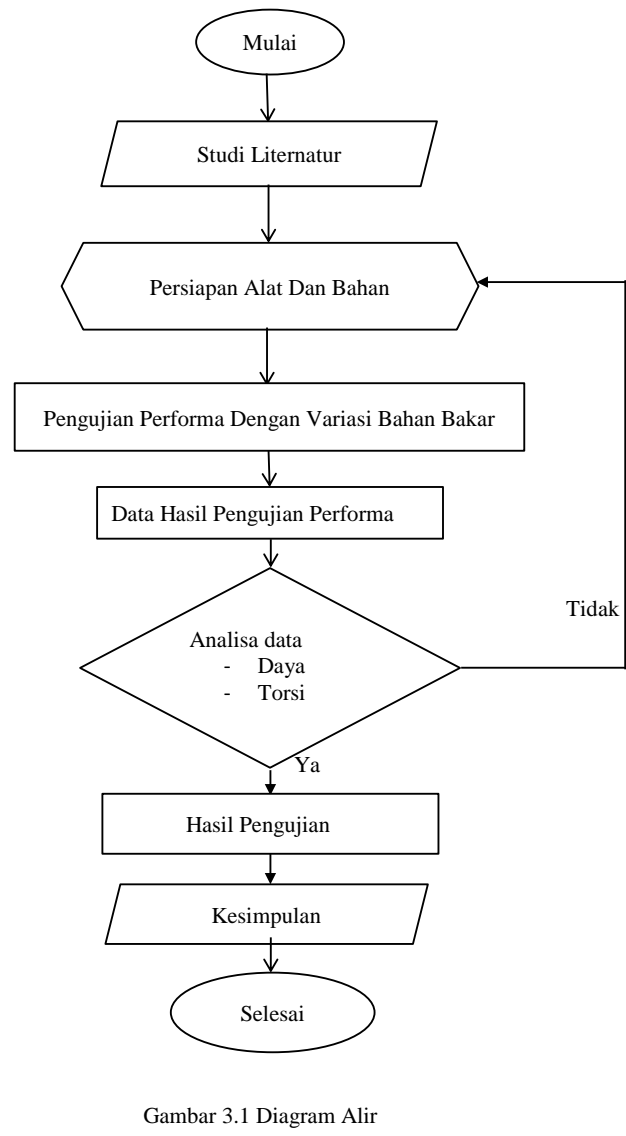

Alat dan Bahan

1. Sepeda motor 4 langkah

2. Premium sebagai bahan bakar standar pemakian harian.

3. Pertalite dan pertamax sebagai bahan bakar penganti dalam ekperimen.

4. Dynotest.

5. Stop watch.

6. Burret.

Tempat dan Waktu Penelitian

\section{Waktu Penelitian}

Waktu yang dibutuhkan peneliti dalam melakukan penelitian ini adalah kurang lebih 1 bulan terhitung sejak bulan Desember 2018, dalam kurun waktu tersebut penulis akan melakukan pengumpulan data, analisis data dan pengolahan data yang selanjutnya akan disajikan dalam bentuk laporan Tugas Akhir serta proses bimbingan berlangsung. 


\section{Tempat Penelitian}

Tempat pelaksanaan penelitian serta pengujian data akan dilakukan di RAT Motor Sport yang berlokasi di Surabaya.

Langkah-Langkah Pengujian

Langkah - langkah pengujian daya dan torsi antara lain:

1. Letakkan kendaraan motor yang akan diuji diatas dynotest dengan posisi roda belakang menempel tepat diatas roller.

2. Pasang penahan pada roda depan dengan diperkuat dengan pengereman agar kendaraan tidak dapat bergerak

3. Nyalakan mesin

4. Atur putaran mesin hingga kondisi stationer, kemudian biarkan beberapa saat untuk pemanasan.

5. Untuk memperoleh nilai torsi pada masing-masing variasi putaran mesin, atur putaran mesin 3000 7000 pada pengujian diketiga jenis bahan bakar yang digunakan (premium, pertalite dan pertamax).

6. Untuk memperoleh nilai torsi maksimal, atur putaran mesin hingga nilai RPM maksimal yang dapat diperoleh mesin.

7. Nilai torsi dibaca pada instrumen dynotest.

\section{HASIL DAN PEMBAHASAN}

\section{Hasil Penelitian}

Setelah melakukan penelitian di RAT Motor Sport Surabaya, peneliti memperoleh data real yang berhubungan dengan pengaruh variasi bahan bakar Grafik Perbandingan Daya dan Rpm Pada Bahan Bakar Premium, Pertalite dan Pertamax

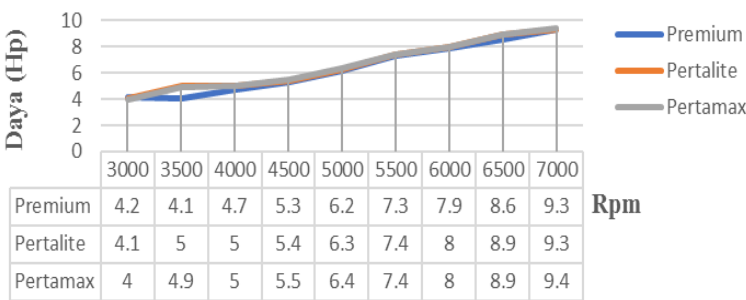

Gambar 4.1 Grafik Perbandingan Daya dan Rpm Pada Bahan Bakar Premium, Pertalite dan Pertamax

Dari tabel dan grafik di atas bisa disimpulkan bahwa Premium, pertalite dan pertamax mencapai daya tertinggi pada putaran 7000 RPM dengan daya yang dihasilkan Premium sebesar 9.3 Hp, Pertalite 9.3 Hp dan Pertamax 9.4 Hp, ini menunjukkan bahwa daya yang dihasilkan oleh variasi bahan bakar (premium, pertalite dan pertamax) memberikan pengaruh yang tidak begitu besar terhadap performa motor injeksi 115 cc tahun 2013, namun melihat kenaikan daya yang dihasilkan oleh masing-masing bahan bakar, pertamax memiliki kenaikan daya lebih cepat dibandingkan dengan bahan bakar lainnya meskipun tidak begitu besar, ini menunjukkan bahwa pada motor injeksi 115 cc tahun 2013 performa mesin akan tetap optimal dengan penggunaan bahan bakar premium, pertalite ataupun pertamax.

Untuk mendapatkan data yang valid maka peneliti juga melakukan perhitungan manual terhadap daya yang sudah dihasilkan, berikut perhitungan manual untuk Daya yang dihasilkan oleh pertamax, pertalite dan premium pada pengujian pertama (lihat pada tabel 4.10) dengan putaran mesin 3500 RPM dan 4500 RPM:

- Perhitungan Pertamax pada putaran mesin 3500RPM

$$
\begin{gathered}
p=\frac{2 \pi n T}{60000}=\frac{2 \cdot 3,14 \cdot 3500 \cdot 9,86}{60000}=3,612 \mathrm{~kW} \\
=4,843 \mathrm{Hp}=4,9 \mathrm{Hp}
\end{gathered}
$$

- Perhitungan Pertamax pada putaran mesin 4500RPM

$$
\begin{gathered}
p=\frac{2 \pi n T}{60000}=\frac{2.3,14.4500 .8,58}{60000}=4,041 \mathrm{~kW} \\
=5,419 \mathrm{Hp}=5,5 \mathrm{Hp}
\end{gathered}
$$

- Perhitungan Pertalite pada putaran mesin 3500 RPM

$$
\begin{gathered}
p=\frac{2 \pi n T}{60000}=\frac{2 \cdot 3,14 \cdot 3500 \cdot 9,91}{60000}=3,360 \mathrm{~kW} \\
=4,868 \mathrm{Hp}=5,0 \mathrm{Hp}
\end{gathered}
$$

- Perhitungan Pertalite pada putaran mesin 4500 RPM

$$
\begin{aligned}
p=\frac{2 \pi n T}{60000}= & \frac{2 \cdot 3,14 \cdot 4500 \cdot 8,43}{60000}=3,970 \mathrm{~kW} \\
& =5,324 \mathrm{Hp}=5,4 \mathrm{H}
\end{aligned}
$$

- Perhitungan Premium pada putaran mesin 3500 RPM

$$
\begin{aligned}
p=\frac{2 \pi n T}{60000}= & \frac{2 \cdot 3,14 \cdot 3500 \cdot 8,27}{60000}=3,029 \mathrm{~kW} \\
& =4,062 \mathrm{Hp}=4,1 \mathrm{Hp}
\end{aligned}
$$

- Perhitungan Premium pada putaran mesin 4500 RPM

$$
\begin{gathered}
p=\frac{2 \pi n T}{60000}=\frac{2 \cdot 3,14 \cdot 4500 \cdot 8,30}{60000}=3,909 \mathrm{~kW} \\
=5,242 \mathrm{Hp}=5,3 \mathrm{Hp}
\end{gathered}
$$


Tabel 4.1 Perbandingan Daya dan Rpm Pada Bahan Bakar Premium, Pertalite dan Pertamax

\begin{tabular}{|c|c|c|c|}
\hline \multirow{2}{*}{ Rpm } & Premium & Pertalite & Pertamax \\
\cline { 2 - 4 } & Daya (Hp) & Daya (Hp) & Daya (Hp) \\
\hline 3000 & 4.2 & 4.1 & 4.0 \\
\hline 3500 & 4.1 & 5.0 & 4.9 \\
\hline 4000 & 4.7 & 5.0 & 5.0 \\
\hline 4500 & 5.3 & 5.4 & 5.5 \\
\hline 5000 & 6.2 & 6.3 & 6.4 \\
\hline 5500 & 7.3 & 7.4 & 7.4 \\
\hline 6000 & 7.9 & 8.0 & 8.0 \\
\hline 6500 & 8.6 & 8.9 & 8.9 \\
\hline 7000 & $\mathbf{9 . 3}$ & $\mathbf{9 . 3}$ & $\mathbf{9 . 4}$ \\
\hline $\begin{array}{c}\text { Rata- } \\
\text { Rata }\end{array}$ & $\mathbf{6 . 4}$ & $\mathbf{6 . 6}$ & $\mathbf{6 . 6 1}$ \\
\hline
\end{tabular}

Tabel 4.2 Perbandingan Torsi dan Rpm Pada Bahan Bakar Premium, Pertalite dan Pertamax

\begin{tabular}{|c|c|c|c|}
\hline \multirow{2}{*}{ Rpm } & Premium & Pertalite & Pertamax \\
\cline { 2 - 4 } & Torsi (N.m) & Torsi (N.m) & Torsi (N.m) \\
\hline 3000 & $\mathbf{9 . 6 7}$ & 9.50 & 9.38 \\
\hline 3500 & 8.27 & $\mathbf{9 . 9 1}$ & $\mathbf{9 . 8 6}$ \\
\hline 4000 & 8.33 & 8.76 & 8.67 \\
\hline 4500 & 8.30 & 8.43 & 8.58 \\
\hline 5000 & 8.66 & 8.83 & 8.94 \\
\hline 5500 & 9.27 & 9.51 & 9.42 \\
\hline 6000 & 9.16 & 9.41 & 9.32 \\
\hline 6500 & 9.23 & 9.55 & 9.54 \\
\hline 7000 & 9.33 & 9.29 & 9.44 \\
\hline $\begin{array}{c}\text { Rata- } \\
\text { Rata }\end{array}$ & $\mathbf{8 . 9 1}$ & $\mathbf{9 . 2 4}$ & $\mathbf{9 . 2 4}$ \\
\hline
\end{tabular}

Grafik Perbandingan Torsi dan Rpm Pada Bahan Bakar Premium, Pertalite dan pertamax

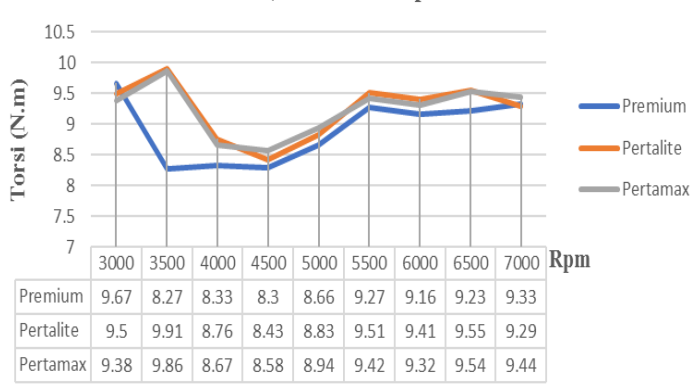

Gambar 4.2 Grafik Perbandingan Torsi dan Rpm Pada Bahan Bakar Premium, Pertalite dan Pertamax
Dari tabel dan grafik diatas dapat dilihat bahwa torsi awal yaitu pada putaran $3000 \mathrm{rpm}$ dari penggunaan bahan bakar premium lebih tinggi dari pada penggunaan bahan pertalite dan pertamax, sedangkan pada putaran di atas $7000 \mathrm{rpm}$ torsi penggunaan bahan bakar premium, pertalite dan pertamax sama-sama menurun.

Torsi maksimum pada mesin motor injection 115 cc tahun 2013 yang mengacu pada penggunaan bahan bakar premium yaitu 9,67 N.m pada putaran mesin $3000 \mathrm{rpm}$ dan torsi maksimum pada bahan bakar pertalite sebesar 9,91 pada putaran mesin $3500 \mathrm{rpm}$. Sedangkan torsi maksimum dengan bahan bakar pertamax yaitu 9.86 N.m pada putaran mesin 3500 rpm.

Besar kecilnya torsi dipengaruhi oleh putaran dan beban mesin. Semakin berat beban pengemudi yang diberikan maka semakin besar pula torsi yang dibutuhkan untuk mencapai kecepatan yang lebih tinggi. Ada beberapa cara untuk meningkatkan nilai torsi dari sebuah mesin yaitu dengan memperbesar langkah piston atau dengan memperbesar volume ruang bakar, namun hal ini akan sangat mempengaruhi efisiensi bahan bakar, konstruksi mesin tersebut.

\section{PENUTUP}

\section{Kesimpulan}

Dari hasil penelitian penganruh pengunaan variasi bahan bakar premium, pertalite dan pertamax terhadap performa motor injeksi $115 \mathrm{cc}$ tahun 2013 dapat diambil kesimpulan sebagai berikut :

1. Torsi tertinggi pada penggunaan jenis bahan bakar premium yaitu 9,67 N.m, pada putaran mesin 3000 rpm dan torsi tertinggi yang dihasilkan pertalite yaitu 9,91 N.m, pada putaran mesin $3500 \mathrm{rpm}$. Sedangkan torsi tertinggi yang dihasilkan pada penggunaan jenis bahan bakar pertamax adalah 9,86 N.m, pada putaran mesin 3500 rpm. Hal ini berarti bahwa torsi tertinggi yang dihasilkan oleh bahan bakar pertalite lebih besar dari pada yang dihasilkan oleh bahan bakar premium dan pertamax. Jadi, torsi bahan bakar pertalite lebih baik atau lebih tinggi dari pada premium dan pertamax.

2. Daya tertinggi yang dihasilkan oleh premium, pertalite dan pertamax pada putaran mesin yang sama yaitu $7000 \mathrm{rpm}$, namun daya yang dihasilkan oleh masing-masing bahan bakar berbeda untuk premium menghasilkan daya tertinggi yaitu sebesar 
9,3 Hp, dan pertalite daya tertingginya adalah 9,3 Hp , sedangkan daya tertinggi pertamax yaitu 9,4 Hp. Dilihat dari hasil daya tertinggi sama dan tidak berbeda jauh, maka hal ini berarti bahwa penggunaan jenis bahan bakar premium, pertalite dan pertamax pada motor injeksi 115 cc tahun 2013 dengan kondisi motor standart tidak memberikan daya yang signifikan. Jika dilihat pada tabel 4.4. hasil pengujian daya bahan bakar premium, pertalite dan pertamax, pada RPM 4000 sampai dengan 7000 pertamax lebih unggul atau lebih tinggi dari pada premium dan pertalite.

3. Dari peneletian yang sudah dilakukan terhadap pengunaan variasi bahan bakar (premium, pertalite dan pertamax) maka pertamax adalah bahan bakar terbaik karena menghasilkan daya dan torsi yang paling besar yaitu 9,4 Hp dan torsi 9,86 N.m, dengan bahan bakar petamax tekanan kompresi yang tinggi dan karakteristik pertamax yang sulit terbakar pada tekanan tinggi membuat pembakaran menjadi sempurna. Hasilnya, akan menimbulkan daya efisien yang maksimum serta konsumsi bahan bakar yang lebih irit.

\section{Saran}

Adapun saran yang bisa penulis berikan dalam penelitian ini adalah sebagai berikut :

1. Pada penelitian selanjutnya diharapkan untuk melakukan penelitian terhadap penggunaan bahan bakar motor dari RON tertinggi ke RON terendah untuk mengetahui perbedaan daya dan torsi yang dihasilkan.

2. Untuk penelitian selanjutnya diharapkan untuk dapat menggunakan bahan bakar yang mempunyai spesifikasi RON yang lebih tinggi dari pertamax seperti pertamax turbo dan menggunakan mesin motor yang berbeda merk.

3. Dari hasil penelitian yang sudah dilakukan terhadap penggunaan variasi bahan bakar (premium, pertalite, pertamax) diperoleh data yang menggambarkan perubahan performa motor yang tidak terlalu besar, oleh karena itu diharapkan pada penelitian selanjutnya bisa memperbesar langkah piston atau dengan memperbesar volume ruang bakar dan bagian kelistrikan seperti bagian pengapian mesin. Karena apabila perubahan yang dilakukan dengan perbandingan jenis bahan bakarnya saja tidak mendapatkan perubahan nilai peforma yang besar.

\section{DAFTAR PUSTAKA}

Arismunandar, Wiranto. (2005). Penggerak Mula Motor Bakar Torak. Penerbit ITB : Bandung

Hartono. T. (2011). Penggunaan bahan bakar premium, pertamax plus pada mesin motor Honda Supra X 100cc. Surakarta : Tugas Akhir Universitas Muhammadiyah Surakarta.

Haryono, G. (1997). Mengenal Motor Bakar. PT. Pabelan : Solo.

Kristanto, P. (2015). "Motor Bakar Torak Teori dan Aplikasi”. Andi Offset.

Muhammad, T. I.. (2014). Part-load performance and emissions of a spark ignition engine fueled with RON95 and RON97 gasoline: Technical viewpoint on Malaysia's fuel price debate. Energy convertion and management 88, 928935.

Muklisanto. (2003). Pengaruh Variasi CampuranPremium Etanol Pada Variasi Rasio Mainjet Terhadap Kinerja Mesin Empat Langkah 110cc. Surakarta : Tugas Akhir Universitas Muhammadiyah Surakarta.

Purnomo, T. B. (2013). Perbedaan performa motor berbahan bakar premium 88 dan motor berbahan bakar pertamax 92. Teknik mesin. Universitas negeri semarang. Semarang.

Surbhakty, 1978. Motor Bakar. Diktat Pendidikan Menengah Teknologi: Jakarta

Sururi E., \& waluyo, B. (2012). Kaji Eksperimental perbandingan penggunaan premium dan pertamax terhadap unjuk kerja mesin pada sepeda motor Suzuki Thunder tipe EN-125. Teknik mesin. Universitas Muhammadiyah Magelang.

Tedjosiswojo, A.s. (2010). Pengaruh Premium dan Pertamax Bagi Perfoma Mesin Motor. Tersedia: https://oto.detik.com/berita/d-1367707/pengaruhpremium-dan-pertamax-bagi-perfoma-mesinmotor [1 Juni 2010] 